\title{
Effect of Obsessive Compulsive Disorder on Word Stem Completion Test (WSCT) and Cognitive Processes
}

\author{
Obsesif Kompulsif Bozukluğun Kelime Kökü Tamamlama Testi (KKTT) ve Bilișsel Süreçlere Etkisi
}

\author{
Emine Fusun Akyuz Cim¹, Adem Aydin², Abdullah Atli3 ${ }^{3}$ Faruk Kurhan ${ }^{4}$ \\ ${ }^{I}$ Department of Psychiatry, Demiroglu Bilim University Faculty of Medicine, Sisli Florence Nightingale Hospital, Istanbul; \\ ${ }^{2}$ Department of Psychiatry, Necmettin Erbakan University Meram Faculty of Medicine, Konya; ${ }^{3}$ Department of Psychiatry, Dicle \\ University Faculty of Medicine, Diyarbakir; ${ }^{4}$ Department of Psychiatry, Yuzuncu Yil University Faculty of Medicine, Van, Turkey
}

\begin{abstract}
Aim: The aim of this study is to evaluate the relationship between implicit memory performance and cognitive processes in individuals with Obsessive-Compulsive Disorder (OCD).

Material and Method: In this study, we aimed to investigate the relationship between implicit memory performance and cognitive processes by comparing a group of 30 Obsessive-Compulsive Disorder $(O C D)$ patients that presented to Yüzüncü Yıl University Medical School Hospital Psychiatry Polyclinic and a group of 40 healthy subjects. Both groups were administered demographic data form and the Word Stem Completion Test (WSCT). The patient group was additionally administered Yale-Brown Obsessive Compulsive Scale (Y-BOCS), Dimensional Yale-Brown ObsessiveCompulsive Scale (DY-BOCS), Metacognitions Questionnaire 30 (MCQ-30), Thought-Action Fusion Scale (TAFS), and Obsessive Beliefs Questionnaire-44 (OBQ-44).

Results: It was determined that the increase in Y-BOCS and cognitive parameters (TAFS, OBQ-44, MCQ-30) scores adversely affected the performance of WSCT. The mean WSCT score was $7.63 \pm 3.05$ in the patient group and $6.30 \pm 2.09$ in the control group $(p=0.034)$. TAF parameter is the most important cognitive parameter affecting implicit memory performance.
\end{abstract}

Conclusion: In OCD, implicit memory performance is adversely affected as the severity of the disease increases.

Key words: obsessive-compulsive disorder; implicit memory; thought-action fusion; metacognition

\section{ÖZET}

Amaç: Bu çalıșmada, Obsesif Kompülsif Bozukluğu (OKB) olan bireylerde örtük bellek performansı ile bilișsel süreçlerin ilișkisinin değerlendirilmesi amaçlandı.

Materyal ve Metot: Bu çalıșma; Yüzüncü Yıl Üniversitesi Tıp Fakültesi Hastanesi Psikiyatri Polikliniğine bașvuran; 30 Obsesif
Kompülsif Bozukluk (OKB) tanılı hasta ve rastgele seçilen 40 kișilik sağlıklı kontrol grubunda örtük bellek performansı ile bilișsel süreçler değerlendirildi. Her iki grup için; örtük bellek performansını değerlendiren Kelime Kökü Tamamlama Testi (KKTT) ve Sosyo-demografik bilgi formu uygulandı. Hasta grubuna ise bu teste ilave olarak, YaleBrown Obsesyon Kompulsiyon Ölçeği (Y-BOCS), Boyutsal YaleBrown Obsesyon Kompulsiyon Ölçeği (DY-BOCS), Obsesyonel Inanıșlar Ölçeği (OiÖ), Düșünce Eylem Kaynașması Ölçeği (TAF) ve Üst Biliș Ölçeği (ÜBÖ) uygulandı.

Bulgular: Yapılan değerlendirme neticesinde; Y-BOCS ve bilișsel parametrelerin (TAF-OIÖ-ÜBÖ) puanlarındaki artıșın KKTT performansını ters yönde etkilediği saptandı. Ortalama KKTT skoru hasta

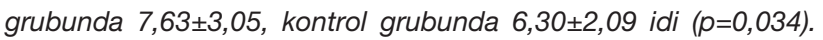
Örtük bellek performansını en fazla etkileyen bilișsel parametre ise TAF parametresi idi.

Sonuç: OKB'da, hastalığın șiddeti arttıkça örtük bellek performansı olumsuz etkilediği saptandı.

Anahtar kelimeler: obsesif-kompulsif bozukluk; örtük bellek; düșünce eylem kaynașması; üst biliș

\section{Introduction}

Memory is classified into two types based on the level of consciousness during information processing: explicit and implicit ${ }^{1}$. Explicit memory is defined as the intentional recollection of information while implicit memory reflects the unintentional recollection of information $^{2,3}$. Moreover, while explicit memory is effective in action planning, implicit memory is independent of verbal processing 4 . 
Implicit memory, first defined by Reber in 1967, is highly useful in the acquisition of sportive and motor skills $s^{5}$. Studies have shown that performance on implicit memory is unrelated to general intelligence and the cognitive function level ${ }^{6}$.

Obsessive-compulsive disorder (OCD) is a psychiatric disorder characterized by obsessions and compulsions. Obsessions are repetitive and unwanted thoughts, urges, or images, while compulsions are repetitive behaviors and cognitive rituals occurring secondary to obsessions. Memory studies in OCD have primarily focused on the elements of explicit memory such as working memory ${ }^{7,8}$, visual-spatial memory, and verbal memory ${ }^{9}$.

Literature reviews indicate a limited number of studies reporting on implicit memory performance in preconscious information processing in OCD patients ${ }^{10}$. While some of these studies have reported that implicit memory is impaired ${ }^{11}$, some others have suggested that it is preserved in OCD patients ${ }^{12}$.

Dysfunctional thoughts have a role in the cognitive models of $\mathrm{OCD}^{13}$. Our present study, the implicit memory performance and the cognitive status of the participants were evaluated. We also evaluated the parameters associated with dysfunctional thoughts in patients with OCD, including obsessive beliefs, metacognition, and thought-action fusion (TAF).

\section{Material and Method}

The study included a total of 70 participants comprising 30 patients that were being treated and followed up due to OCD in Yüzüncü Yil University Medical School Training and Research Hospital Psychiatry Clinic and 40 healthy subjects. Local ethics committee approval was obtained before the study (YYU-2012-02). Participation consent form was obtained from the participants.

The criteria for inclusion in the control group were being 18-55 years of age, absence of any psychiatric pathology according to DSM-V criteria, absence of neurological disease and normal mental capacity. Criteria for inclusion in the case group $=$ Obsessive-compulsive disorder diagnosis, absence of psychotic symptoms, normal mental capacity.

The patients were administered sociodemographic data form, Yale-Brown Obsessive Compulsive Scale (Y-BOCS), Dimensional Yale-Brown ObsessiveCompulsive Scale (DY-BOCS), Metacognitions Questionnaire-30 (MCQ-30), Thought-Action Fusion Scale (TAFS), Obsessive Beliefs Questionnaire-44
(OBQ-44) and Word Stem Completion Test (WSCT). In contrast, the healthy subjects were administered demographic data form and WSCT only.

\section{Sociodemographic Data Form}

The sociodemographic data form was developed by the researchers to assess patients' sociodemographic (age, gender, marital status, occupation, educational level and status, socioeconomic status) and clinical (prior diseases and OCD-related conditions) characteristics.

\section{Yale-Brown Obsessive Compulsive Scale (Y-BOCS)}

Yale-Brown Obsessive Compulsive Scale (Y-BOCS) is a clinician-administered scale for the assessment of the type and severity of OCD symptoms. Y-BOCS consists of 19 items and each item is rated on a scale of 0-4. Adaptation, validity, and reliability studies have been conducted by Karamustafalioglu et al. ${ }^{14}$.

\section{Dimensional Yale-Brown Obsessive-Compulsive Scale (DY-BOCS)}

The DY-BOCS is a interview-based scale for assessing the severity of OCD. It has 88 -item OCD symptoms checklist for each OCD symptoms dimension.

\section{Metacognitions Questionnaire-30 (MCQ-30)}

The term 'metacognition' was first coined by Flavell ${ }^{15}$, referring to one's knowledge concerning the system, structure, and the function of one's own cognitive processes. The short form of the scale has 30 items (MCQ-30).

\section{Thought-Action Fusion Scale (TAFS)}

Thought-Action Fusion (TAF) is another cognitive parameter measured in our study. TAF refers to the belief that thinking about an action is equivalent to actually carrying out that action. Thought-Action Fusion Scale (TAFS) consists of 5-point Likerttype items. Adaptation study has been conducted by Yorulmaz et al. ${ }^{16}$.

\section{Obsessive Beliefs Questionnaire-44 (OBQ-44)}

Obsessive Beliefs Questionnaire 44 (OBQ-44) is a $44-$ item scale developed for assessing non-objective belief domains contributing to the conversion of intrusive thoughts to clinical obsessions. The scale consists of 3 subscales: (I) responsibility and threat estimation, (II) importance and control of thoughts, and (III) perfectionism and intolerance of uncertainty. Adaptation, validity, and reliability studies have been conducted by Besiroglu et al. ${ }^{17}$. 
Word Stem Completion Test (WSCT)

Word Stem Completion Test (WSCT) is used for measuring the preparatory effect of repetition on learning and memory. Adaptation study has been conducted by Tavat and $\mathrm{Can}^{18}$.

The WSCT test consists working phase and intermediate phase. 25 pairs of words are used in the study phase. Participants evaluate 25 words on the first page with implicit coding at the first part of study phase. In the intermediate step, the names of the famous are given and the participants are asked to fill the surnames of the famous. In the last step of the study phase, the first syllables of the 25 words are given. The 25 completed words are compared to the words on the first worksheet. The participant is asked to fill the first syllables with the first word that will come into their mind. The first two words are excluded due to the primacy effect and the last two words are excluded from the analysis due to the recency effect.

Data were analyzed using SPSS 16.0 for Windows (SPSS Inc., Chicago, IL, USA). Correlations were analyzed using Pearson Product-Moment Correlation Coefficient (PPMCC). A $p$ value of $<0.05$ was considered significant.

Table 1. Mean age and WSCT scores in both groups

\begin{tabular}{lccc}
\hline & $\begin{array}{c}\text { Patient group } \\
(\mathrm{n}=30)\end{array}$ & $\begin{array}{c}\text { Control group } \\
(\mathrm{n}=40)\end{array}$ & $\mathrm{p}$ value \\
\hline Mean age (years) & $30.63 \pm 7.95$ & $31.27 \pm 9.11$ & 0.759 \\
Mean WSCT score & $7.63 \pm 3.05$ & $6.30 \pm 2.09$ & 0.034 \\
\hline
\end{tabular}

Values are given as mean \pm standard deviation (SD).

$A p$ value of $<0.05$ was considered significant.

Table 2. Correlation coefficients in the patient group (PPMCC)

\begin{tabular}{|c|c|c|c|c|c|c|}
\hline & 1. WSCT & 2. Y-BOCS & 3. DY-BOSCS & 4. $0 B Q-44$ & 5. TAFS & 6. MCQ-30 \\
\hline 1. WSCT & - & & & & & \\
\hline 2. Y-BOCS & $-0.84^{* *}$ & - & & & & \\
\hline 3. DY-BOCS & $-0.83^{* *}$ & 0.96 ** & - & & & \\
\hline 4. $0 \mathrm{BQ}-44$ & $-0.52^{* *}$ & 0.60 ** & $0.62^{* *}$ & - & & \\
\hline 5. TAFS & $-0.78^{* *}$ & $0.74^{* *}$ & $0.77^{* \star}$ & 0.80 ** & - & \\
\hline 6. MCQ-30 & $-0.70^{* *}$ & $0.53^{* *}$ & 0.60 ** & 0.60 ** & 0.79 ** & - \\
\hline
\end{tabular}

Pearson moments multiplication correlation coefficients calculated between variables in the patient group.

${ }^{* *} \mathrm{p}<0.05$

Y-BOCS: Yale-Brown Obsessive Compulsive Scale, DY-BOCS: Dimensional Yale-Brown Obsessive-Compulsive Scale, MCQ-30: Metacognitions Questionnaire-30, TAFS: Thought-Action Fusion Scale,

OBQ-44: Obsessive Beliefs Questionnaire-44, WSCT: Word Stem Completion Test.

Mean age was $30.63 \pm 7.95$ years in the patient group and $31.27 \pm 9.11$ years in the control group. Age had no significant effect on WSCT scores $(\mathrm{p}=0.759)$ and the correlation coefficient between age and WSCT scores was -0.329 . Moreover, no significant difference was found between the patient and control groups with regard to age ( $\mathrm{t}$ test $=-0.307 ; \mathrm{p}=0.759)$. Mean WSCT score was $7.63 \pm 3.05$ in the patient group and $6.30 \pm 2.09$ in the control group. The $t$-test indicated that the WSCT scores were significantly higher in the patient group compared to the control group $(\mathrm{t}$ test $=2.167 ; \mathrm{p}=0.034)$ (Table 1$)$.

Table 2 presents the correlations between the scores of the scales administered in the patient group and the severity of OCD symptoms. Accordingly, Pearson Product-Moment Correlation Coefficient (PPMCC) indicated a strong negative correlation between WSCT scores and the severity of OCD symptoms. Correlations were found between the OBQ-44, MCQ-30, TAFS, Y-BOCS, DY-BOCS scores and the WSCT scores.

The scores of the scales indicating the severity of OCD symptoms (Y-BOCS and DY-BOCS) and of the scales used for the measurement of cognitive functions (TAFS, OBQ-44, and MCQ-30) increased, the performance on WSCT decreased. Of the cognitive parameters analyzed in the study, TAF was the most effective parameter on the WSCT performance.

\section{Discussion}

\section{patients ${ }^{2}$. In these studies, age and the coexistence of dementia were used as the primary criteria for the selec- tion of patients for the evaluation of implicit memory. \\ Implicit memory was primarily evaluated in amnesic}


Although the WSCT performance can be affected by frontal lobe degeneration, it may not be affected until the age of $70-80$ years $^{19}$. Additionally, it has also been shown that the performance on perceptual implicit memory may not be affected even in patients with severe neuropathological symptoms ${ }^{20}$.

Implicit learning is different in adults from that in children. Adults often use explicit memory while children appear to excel in implicit memory for the acquisition of cognitive skills ${ }^{21}$. Moreover, studies have shown that children have a better implicit memory capacity compared to adults ${ }^{22}$.

In our study however, age had no significant effect on the WSCT performance. Meaningfully, the studies indicating a significant effect of age on the WSCT performance have evaluated both children and adults. However, our study had a relatively narrow age range.

Some of the studies investigating the association between implicit memory and OCD have reported that implicit memory is protected ${ }^{12}$ while the others have suggested that it is reduced ${ }^{23}$ in OCD patients. In our study, the scores of the scales indicating the severity of OCD symptoms (Y-BOCS and DY-BOCS) and of the scales used for the measurement of cognitive functions (TAFS, OBQ-44, and MCQ-30) increased, the performance on WSCT decreased.

The inconsistency among the studies investigating implicit memory performance in OCD patients could be related to the drugs used by the patients included in these studies ${ }^{24}$. Of these drugs, selective serotonin reuptake inhibitors (SSRIs) are known to have a potential to reduce the symptoms and to reverse the hyperactivity in the striatum and associated frontal regions ${ }^{25}$. Based on these findings, it is safe to assert that drug use can increase the WSCT performance. In our study, the patient group was heterogeneous in terms of drug use.

In OCD patients, implicit memory deficits are compensated by the performance on hippocampus-dependent explicit memory ${ }^{26}$. Hypothetically, then, implicit memory performance could have a compensatory effect on explicit memory deficits. In our study, however, no evaluation was performed for explicit memory performance.

There is a positive clinical relationship between OCD and implicit memory. Implicit contextual information is considered to reduce anxiety caused by obsessive behaviors $^{27}$.
In our study, as the Y-BOCS and DY-BOCS scored increased, the WSCT scores decreased, which implicates that there is an inverse relationship between the effect on implicit memory functions and the severity of OCD symptoms.

The flexibility in cognitive processes can be affected by OCD. The response of implicit information to a stimulus can be less variable and biased. Explicit memory deficits are mostly seen in patients with repetitive control ritual $s^{28}$. Therefore, good implicit memory performance could be expected to reduce the severity of the disorder. According to our study result; the implicit memory performance was impaired with the severity of the disorder.

In our study, the increase in cognitive parameters (thought-action fusion, obsessive beliefs, and metacognition) had an adverse effect on the WSCT performance, with the highest effect seen in TAF. This finding could be explained by the relationship between the severity of the disease and these parameters, as in the relationship between the severity of the disease and Y-BOCS and DY-BOCS. The severity of the disease may also be affecting the WSCT performance besides implicit memory performance like explicit memory.

Thought-action fusion (TAF) refers to the tendency to assume that certain thoughts increase the likelihood of catastrophic events. TAF can lead to pathological anxiety and adverse effects even in the absence of obsessive symptoms ${ }^{29}$. TAF is also effective in the etiology and progression of OCD. Additionally, TAF is a fundamental factor that can cause variation in the elements involved in the phenomenology of OCD, such as responsibility and overthinking ${ }^{30}$.

As TAF is independent from obsessive symptoms and has a key role in the progression of these symptoms, it is considered to be dissimilar to other cognitive parameters. Nevertheless, further studies are needed to investigate the relationship between TAF and implicit memory performance.

Our study was limited since the patient group was heterogeneous in terms of drug use and no evaluation was performed for explicit memory performance.

The severity of OCD increases, the implicit memory performance decreases. TAF was found to be the most effective cognitive parameter on implicit memory performance. Further studies evaluating explicit memory performance in patients receiving no pharmacological 
treatment are needed to provide a deeper insight into the relationship between implicit memory and the cognitive dysfunction in OCD patients.

\section{Conflict of Interest}

No conflict of interest was declared by authors.

\section{Financial Disclosure}

The authors declared that this study received no financial support.

\section{References}

1. Schacter DL. Implicit memory: History and current status. Journal of Experimental Psychology: Learning, Memory, and Cognition 1987;13(3):501-18.

2. Graf P, Schacter DL. Implicit and explicit memory for new associations in normal and amnesic subjects. Journal of Experimental Psychology: Learning, Memory, and Cognition 1985;11(3):501-18. doi:10.1037/0278-7393.11.3.501.

3. Roediger HL. Implicit memory: Retention without remembering. American Psychologist 1990;45(9):1043-56.

4. Heuer H, Schmidtke V. Secondary-task effects on sequence learning. Psycholological Research 1996;59:119-33.

5. Reber AS. Implicit learning of artificial grammars. Journal of Verbal Learning and Verbal Behavior 1967;6(6):855-63.

6. Gebauer GF, Mackintosh NJ. Psychometric intelligence dissociates implicit and explicit learning. Journal of Experimental Psychology: Learning, Memory, and Cognition 2007;33(1):34-54. doi:10.1037/0278-7393.33.1.34.

7. Li B, Mody M. Cortico-striato-thalamo-cortical circuitry, working memory and obsessive-compulsive disorder. Front Psychiatry 2016;7:78. doi:10.3389/fpsyt.2016.00078.

8. Diwadkar VA, Burgess A, Hong E, Rix C, Arnold PD, Hanna GL, et al. Dysfunctional activation and brain network profiles in youth with obsessive-compulsive disorder: a focus on the dorsal anterior cingulate during working memory. Front Hum Neurosci 2015;9:149. doi:10.3389/fnhum.2015.00149.

9. Batistuzzo MC, Balardin JB , Martin Mda G, Hoexter MQ , Bernardes ET, Borcato S, et al. Reduced prefrontal activation in pediatric patients with obsessive-compulsive disorder during verbal episodic memory encoding. J Am Acad Child Adolesc Psychiatry 2015;54(10):849-907. doi: 10.1016/j. jaac.2015.06.020.

10. Park SE, Yang JC, Jeong GW. Neuroanatomical assessment of the impact of negative emotion on implicit memory in patients with obsessive compulsive disorder. Acta Neuropsychiatr 2016;28(4):206-13. doi: 10.1017/neu.2015.63.

11. Deckersbach T, Savage CR, Curran T, Bohne A, Wilhelm S, Baer L, et al. A study of parallel implicit and explicit information processing in patients with obsessive-compulsive disorder. Am J Psychiatry 2002;159(10):1780-82.
12. Foa EB, Amir N, Gershuny B, Molnar C, Kozak MJ. Implicit and explicit memory in obsessive-compulsive disorder. J Anxiety Disord 1997;11(2):119-29.

13. Fisher PL, Wells A. Metacognitive therapy for obsessivecompulsive disorder: A case series. Journal of Behavior Therapy and Experimental Psychiatry 2008;39(2):117-32. doi:10.1016/j.jbtep.2006.12.001.

14. Karamustafalıoglu KO, Üçısık AM, Ulusoy M, Erkmen H. Validity and reliability study of the Yale-Brown Obsessive Compulsive Scale, Bursa: Savas Ofset; 1993:86.

15. Flavell JH. Metacognition and cognitive monitoring: A new area of cognitive-developmental inquiry. American Psychologist 1979;34(10):906-11. doi:10.1037/0003066X.34.10.906.

16. Yorulmaz O, Yılmaz AE, Gençöz T. Psychometric properties of the Thought-Action Fusion Scale in a Turkish sample. Behaviour Research Therapy 2004;42(10):1203-14. doi:10.1016/j. brat.2003.08.005.

17. Boysan M, Besiroglu L, Çetinkaya N, Atlı A, Aydın A. The validity and reliability of the Turkish version of the Obsessive Beliefs Questionnaire-44 (OBQ-44). Nöropsikiyatri Arşivi 2010;47(3):216-22. doi:10.4274/npa.5454.

18. Tavat B. Implicit and Open Directives, The Effect of Coding and Presentation Type on New Approaches. Unpublished Master's Thesis, Hacettepe University, Ankara; 1991.

19. Light LL, Singh A. Implicit and explicit memory in young and older adults. Journal of Experimental Psychology: Learning, Memory, and Cognition 1987;13(4):531-41. doi:10.1037/02787393.13.4.531.

20. Fleischman DA, Wilson RS, Gabrieli JDE, Schneider JA, Bienias JL, Bennett DA. Implicit memory and Alzheimer's disease neuropathology. Brain 2005;128(9):2006-15. doi:10.1093/ brain/awh559.

21. Smalle EHM, Page MPA, Duyck W, Edwards M, Szmalec A. Children retain implicitly learned phonological sequences better than adults: a longitudinal study. Dev Sci 2018;21(5):e12634. doi: 10.1111/desc. 12634 .

22. Ullman MT. Contributions of memory circuits to language: the declarative/ procedural model. Cognition 2004;92(1-2):23170. doi:10.1016/j.cognition.2003.10.008.

23. Kim MS, Kim YY, Kim EN, Lee KJ, Ha TH, Kwon JS. Implicit and explicit memory in patients with obsessive-compulsive disorder: an event-related potential study. J Psychiatr Res 2006;40(6):541-49. doi: 10.1016/jpsychires.2005.05.007.

24. Kelmendi B, Adams T Jr, Jakubovski E, Hawkins KA, Coric V, Pittenger C. Probing Implicit Learning in ObsessiveCompulsive Disorder: Moderating Role of Medication on the Weather Prediction Task. J Obsessive Compuls Relat Disord 2016;9:90-5. doi: 10.1016/j.jocrd.2016.03.003.

25. Atmaca M. The Effects of Psychopharmacologic and Therapeutic Approaches on Neuro-imaging in Obsessivecompulsive Disorder. Curr Neuropharmacol 2013;11(1):10913. doi: 10.2174/157015913804999414. 
26. Rauch SL, Wedig MM, Wright CI, Martis B, McMullin KG, Shin LM, et al. Functional magnetic resonance imaging study of regional brain activation during implicit sequence learning in obsessive-compulsive disorder. Biol Psychiatry 2007;61(3):330-36. doi: 10.1016/j.biopsych.2005.12.012.

27. Gu BM, Kukreja K. Obsessive-compulsive disorder and memory-mixing in temporal comparison: is implicit learning the missing link? Front Integr Neurosci 2011;5:38. doi: 10.3389/ fnint.2011.00038.

28. Hezel DM, McNally RJ. A Theoretical review of cognitive biases and deficits in obsessive-compulsive disorder. Biol Psychol 2016;121:221-232. doi: 10.1016/j. biopsycho.2015.10.012.
29. Abramowitz JS, Whiteside S, Lynam D, Kalsy S. Is thoughtaction fusion specific to obsessive-compulsive disorder?: a mediating role of negative affect. Behaviour Research Therapy 2003;41(9):1069-79. doi: 10.1016/s00057967(02)00243-7.

30. Amir N, Freshman M, Ramsey B, Neary E, Brigidi B. Thoughtaction fusion in individuals with OCD symptoms. Behaviour Research Therapy 2001;39(7):765-76. doi:10.1016/S00057967(00)00056-5. 